Original article

DOI: https://doi.org/10.21285/2227-2925-2021-11-4-523-530

\title{
Chemical composition and antimicrobial activity of essential oils extracted from Amomum muricarpum Elmer from North Vietnam
}

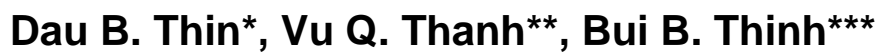 \\ ${ }^{*}$ Hong Duc University, Thanh Hoa, Vietnam \\ ${ }^{*}$ Vietnam-Russia Tropical Center, Hanoi, Vietnam \\ ${ }^{* * *}$ Far Eastern Federal University, Vladivostok, Russian Federation \\ Corresponding author: Bui B. Thinh, buibaothinh9595@gmail.com
}

\begin{abstract}
Recent years have seen the development of bacterial resistance to currently available antibiotics, which necessitates a search for new antimicrobial agents. Amomum muricarpum Elmer is a widely used medicinal plant species in the genus Amomum (family Zingiberaceae) that is commonly found in Laos, the Philippines, China, and Vietnam. The present article describes the chemical composition and antimicrobial activity of essential oils extracted from the leaves and rhizomes of $A$. muricarpum from North Vietnam. The hydrodistilled essential oil was analyzed using gas chromatography and gas chromatography-mass spectrometry, with the broth microdilution method designed to evaluate its antimicrobial efficacy. The absolute yield of essential oils amounted to $0.11 \%$ and $0.13 \%(\mathrm{~V} / \mathrm{w})$ for leaves and rhizomes, respectively, on a dry weight basis. It was found that the leaves and rhizomes of $A$. muricarpum produce oils abounding in monoterpenes. Of the total identified volatile components in the leaf oil (97.18\%), three main constituents include $\alpha$-pinene (40.45\%), linalool (12.34\%), and $\beta$-pinene (10.31\%). In the rhizome oil, the main constituents include $\alpha$-pinene (48.10\%), $\beta$-pinene (20.32\%), and linalool (7.56\%) of the total identified volatile components (98.08\%). An antimicrobial activity test indicates that essential oils from the leaves and rhizome of $A$. muricarpum inhibit the growth of Staphylococcus aureus ATCC 25923, with a minimum inhibitory concentration (MIC) of $200 \mu \mathrm{g} / \mathrm{ml}$. In addition, the rhizome essential oil also exhibits antimicrobial activity against Bacillus cereus ATCC 14579, with a MIC value of $200 \mu \mathrm{g} / \mathrm{ml}$. The results indicate the potential of essential oils extracted from A. muricarpum as a source of antimicrobial agents.
\end{abstract}

Keywords: Amomum muricarpum, Zingiberaceae, essential oil, monoterpenes, $\alpha$-pinene, antimicrobial activity

For citation: Thin D. B., Thanh V. Q., Thinh B. B. Chemical composition and antimicrobial activity of essential oils extracted from Amomum muricarpum Elmer from North Vietnam. Izvestiya Vuzov. Prikladnaya Khimiya $i$ Biotekhnologiya $=$ Proceedings of Universities. Applied Chemistry and Biotechnology. 2021;11(4):523-530. (In English). https://doi.org/10.21285/2227-2925-2021-11-4-523-530.

Научная статья

ФИЗИКО-ХИМИЧЕСКАЯ БИОЛОГИЯ

УдК 547.913

\section{Химический состав и антимикробная активность эфирных масел Amomum muricarpum Elmer из Северного Вьетнама}

\author{
Дау Ба Тхин*, Ву Кует Тхань**, Буй Бао Тхинь*** \\ *Университет Хонгдык, г. Тханьхоа, Вьетнам \\ ${ }^{* *}$ Российско-Вьетнамский Тропический центр, г. Ханой, Вьетнам \\ ***Дальневосточный федеральный университет, г. Владивосток, Российская Федерация \\ Автор, ответственный за переписку: Буй Бао Тхинь, buibaothinh9595@gmail.com
}

Аннотация. В последние годы развитие устойчивости бактерий к антибиотикам потребовало поиска новых противомикробных средств. Aтотит muricarpum Elmer - это вид рода Aтотит семейства Zingiberaceae (Имбирные), распространенный в Лаосе, Филиппинах, Китае и Вьетнаме, широко используемый как лекарственное растение. В данной статье описан химический состав и антимикробная активность эфрирных масел из листьев и корневищ A. muricarpum, собранных в Северном Вьетнаме. Эфирное масло, полученное гидродистилляцией, было проанализировано с использовани-

(C) Thin D. B., Thanh V. Q., Thinh B. B., 2021 
Thin D. B., Thanh V. Q., Thinh B. B. Chemical composition and antimicrobial activity ...

Тхин Д. Б., Тхань В. К., Тхинь Б. Б. Химический состав и антимикробная активность ...

ем газовой хроматографии и газовой хроматографии-масс-спектрометрии, тогда как анализ с микроразбавлением бульона был разработан для оценки его антимикробной эфффективности. Абсолютный выход эфрирных масел составил 0,11\% и 0,13\% (об/масс.) соответственно для листьев и корневищ в пересчете на сухой вес. Анализ масел из листьев и корневищ А. тиricarpum показал, что в масле преобладают монотерпены. В масле листьев из общего количества идентифицированных летучих компонентов $(97,18 \%)$ три составляющих - $\alpha$-пинен $(40,45 \%)$, линалоол $(12,34 \%)$ и $\beta$-пинен (10,31\%), являлись основными. В масле корневища основными из общего количества идентифицированных летучих компонентов (98,08\%) являлись следующие: $\alpha$-пинен $(48,10 \%), \beta$-пинен $(20,32 \%)$ и линалоол (7,56\%). Тест на антимикробную активность показал, что эфирные масла из листьев и корневища A. muricarpum подавляют pocm Staphylococcus aureus ATCC 25923 со значением минимальной ингибирующей концентрации (МИК) 200 мкг/мл. Кроме того, эфрирное масло корневища проявляло антимикробную активность и в отношении Bacillus cereus ATCC 14579 со значением МИК 200 мка/мл. Результаты указывают на потенциал эфрирных масел A. тиricarpuт как источника противомикробных агентов.

Ключевые слова: Amomum muricarpum, семейство Имбирные, эфирное масло, монотерпены, $\alpha$-пинен, антимикробная активность

Для цитирования: Тхин Д. Б., Тхань В. К., Тхинь Б. Б. Химический состав и антимикробная активность эфирных масел Amomum muricarpum Elmer из Северного Вьетнама // Известия вузов. Прикладная химия и биотехнология. 2021. Т. 11. N 4. С. 523-530. https://doi.org/10.21285/2227-29252021-11-4-523-530.

\section{INTRODUCTION}

Since immemorial times, it has been known that the chemical constituents of essential oils of various plants are biologically and pharmacologically active natural substances $[1,2]$. Therefore, greater attention has been paid to the screening of essential oils for their biological activity, as a source of developing new therapeutic agents for the prevention and amelioration of natural ailments caused by microorganisms $[3,4]$. In continuation of our research on the chemical compounds and biological activities of essential oils from Vietnamese Zingiberaceae plants, we report our findings on the chemical composition and antimicrobial activity of essential oils of Amomum muricarpum.

Amomum is a large genus in the Zingiberaceae family distributed in Asia, Africa, and Australia with about 180 species [5]. Amomum plants have been described as sources of biologically active components [4, 6-8]. A. muricarpum is a medicinal plant that can grow up to $2.5 \mathrm{~m}$ tall ${ }^{1}$. Phytochemical investigation of $A$. muricarpum led to the iden-tification of diarylheptanoids $[9,10]$. Previously, the compositions and biological activities of essential oils from various parts of $A$. muricarpum from Central Vietnam were determined and reported [11-14]. Studies noted the effects of geographical and envi-ronmental factors, on the composition and quality of the essential oil [15-17]. This article will provide new data on the chemical composition and antimicrobial activety of essential oils extracted from A. mu-ricarpum, which was grown in North Vietnam.

\section{MATERIALS AND METHODS}

Plant material. The plant parts used for this study namely the leaves and rhizomes of $A$. muricarpum were collected from Na Hang, Tuyen Quang Province, Northern Vietnam in July 2018. Botanical identification was performed by Assoc. Prof. Dr. Dau Ba Thin. Leaves and rhizomes of $A$. muricarpum were dried at room temperature $\left(25^{\circ} \mathrm{C}\right)$ for one week before hydrodistillation.

Hydrodistillation of essential oils. Essential oils were obtained from leaves and rhizomes of $A$. muricarpum (two kilogram for each extraction) by hydrodistillation using a Clevenger-type apparatus for $4 \mathrm{~h}$ at normal pressure according to the pro-cedure of the Vietnamese Pharmacopoeia ${ }^{2}$. The process of hydrodistillation using a Clevenger type apparatus has obtained a mixture of oil with a quantity of water. To remove water, the extracted essential oils were then dried by adding anhydrous sodium sulfate- $\mathrm{Na}_{2} \mathrm{SO}_{4}$. The absorption of water into the sodium sulfate is complete in seconds, causing the grains to coagulate. If additional sodium sulfate is added, and the grains do not coagulate, then the oil is essentially anhydrous. The obtained oils were stored in dry amber vials at $4^{\circ} \mathrm{C}$ until analysis. All measurements were performed in triplicate.

Analysis of essential oils. Gas chromatography (GC) analysis was performed on Agilent GC 7890A equipped with a FID and fitted with HP-5MS column $(30 \mathrm{~m} \times 0.25 \mathrm{~mm}$, film thickness $0.25 \mu \mathrm{m}$, Agilent Technology). The analytical conditions were: carrier gas Helium (1 ml/min), injector temperature (PTV) $250^{\circ} \mathrm{C}$, detector temperature $260^{\circ} \mathrm{C}$, column temperature programmed from $60^{\circ} \mathrm{C}$ (2 min hold) to $220^{\circ} \mathrm{C}(10 \mathrm{~min}$ hold) at the heating rate $4^{\circ} \mathrm{C} / \mathrm{min}$. Samples were injected by splitting and the split ratio was 10:1. The volume injected was $1.0 \mu \mathrm{L}$. Inlet pressure was $6.1 \mathrm{kPa}$.

\footnotetext{
${ }^{1}$ Nguyen T.B. Flora of Vietnam. Vol. 1. Hanoi: Science and Technology Publishing House, 2000.

${ }^{2}$ Vietnamese Pharmacopoeia. Medical Publishing House, 2nd Edition, Hanoi, Vietnam, 2009.
} 
Thin D. B., Thanh V. Q., Thinh B. B. Chemical composition and antimicrobial activity ...

Тхин Д. Б., Тхань В. К., Тхинь Б. Б. Химический состав и антимикробная активность ...

An Agilent GC 7890A chromatograph fitted with a fused silica capillary HP-5MS column $(30 \mathrm{~m} \times 0.25 \mathrm{~mm}$, film thickness $0.25 \mu \mathrm{m})$ and interfaced with a mass spectrometer HP 5973 MSD was used for the GC/MS analysis, under the same conditions as those used for GC analysis. The conditions were the same as described above with Helium ( $1 \mathrm{ml} / \mathrm{min})$ as carrier gas. The MS conditions were as follows: ionization voltage $70 \mathrm{eV}$; emission current $40 \mathrm{~mA}$; scan mass range of 35-350 amu at a sampling rate of $1.0 \mathrm{scan} / \mathrm{s}$.

The identification of constituents from the GC/MS spectra of $A$. muricarpum was performed on the basis of retention indices (RI) determined with reference to a homologous series of $n$-alkanes, under identical experimental conditions, co-injection with standards (Sigma-Aldrich, St. Louis, MO, USA) or known essential oil constituents, MS library search ${ }^{3}$ and as described in previous studies [11-14].

Antimicrobial screening. Antimicrobial activity of A. muricarpum essential oil was carried out on three Gram-negative bacteria, Escherichia coli ATCC 25922, Pseudomonas aeruginosa ATCC 27853, and Salmonella enterica ATCC 13076; three Grampositive bacteria, Enterococcus faecalis ATCC 299212, Staphylococcus aureus ATCC 25923, and Bacillus cereus ATCC 14579; and the yeast, Candida albicans ATCC 10231, using the microdilution broth susceptibility assay as previously described [18]. Testing media included Mueller-Hinton Agar (MHA) used for bacteria and Sabouraud Agar (SA) used for fungi. The minimum inhibitory concentration (MIC) values were determined as the lowest concentration of the test sample that completely inhibits the growth of microorganisms. All measurements were performed in triplicate.

Statistical analysis. All results of chemical composition and antimicrobial experiments were repeated three times and are expressed as mean \pm standard deviation (SD).

\section{RESULTS AND DISCUSSION}

Yields and chemical constituents of essential oils. Hydrodistilled essential oils from the leaves and rhizomes of $A$. muricarpum are analyzed by GC/MS. The yields of the essential oils were 0.11 and $0.13 \%$ $(\mathrm{v} / \mathrm{w}, \pm 0.01)$ respectively for the leaf and rhizome of A. muricarpum. All the essential oils were yellow coloured. The identities of the compounds of A. muricarpum oils, their per cent compositions and retention indices on HP-5MS column could be seen in Table 1.

A total of 45 compounds amounting to $97.18 \%$ in the A. muricarpum leaf essential oil were identified (Table 1). Among these $59.53 \%$ were monoterpene hydrocarbons, $17.71 \%$ were oxygenated monoterpenes, and it also contained $17.59 \%$ sesquiter- pene hydrocarbons and $2.14 \%$ oxygenated sesquiterpenes. The major constituents in the A.muricarpum leaf essential oil were $\alpha$-pinene $(40.45 \%)$, linalool (12.34\%), and $\beta$-pinene (10.31\%). Comparing our results with those obtained by previous studies showed that all the leaf essential oils extracted are similar with $\alpha$-pinene and $\beta$-pinene predominating [11-13]. However, although 1,8-cineole was the second major component in the previous studies $[12,13]$, this component was not detected in the leaf oil of $A$. muricarpum in the present study. Furthermore, linalool (12.34\%) was found at relatively high amounts in the leaf oil of $A$. muricarpum in the present study (Table 1), while this component was in much lower amounts in the previous studies $[12,13]$. The variations in chemical constituents can likely be attributed to the different geographical collection sites as well as climatic factors.

In the essential oil extracted from A. muricarpum rhizome, 44 compounds were identified, corresponding to $98.08 \%$ of the total oil (Table 1 ). It is comprised of monoterpene hydrocarbons $(75.83 \%)$, oxygenated monoterpenes (10.76\%), sesquiterpene hydrocarbons $(10.52 \%)$, and oxygenated sesquiterpenes $(0.81 \%)$. The main constituents in the $A$. $m u$ ricarpum rhizome essential oil were $\alpha$-pinene $(48.10 \%), \beta$-pinene $(20.32 \%)$, and linalool $(7.56 \%)$. To the best of our knowledge, there are several reports on the chemical composition of $A$. muricarpum rhizome oil [11-14]. Most of these reports indicate that $\alpha$-pinene and $\beta$-pinene are the main and/or characteristic constituents of rhizome oil. The findings on the major components of $A$. muricarpum rhizome oil were in agreement with the previous reports except for linalool, which was found to be $7.56 \%$ in our study. As highlighted previously, this difference can also be attributed to growth, genetics, and climatic conditions.

Antimicrobial Activity. The antimicrobial activities of essential oils from the leaf and rhizome of $A$. muricarpum were estimated by means of the microdilution broth method and the results are expressed as the minimum inhibitory concentration (MIC) in Table 2. The rhizomes oil had moderate bactericidal activities against $S$. aureus and $B$. cereus with the MIC value of $200 \mu \mathrm{g} / \mathrm{mL}$. The leaves oil only exhibited antimicrobial action against the growth of S. aureus with a MIC value of $200 \mu \mathrm{g} / \mathrm{mL}$. The observed antimicrobial result of $A$. muricarpum essential oils was in agreement with previous information that Amomum essential oils from Vietnam and other parts of the world selectively inhibited the growth of different microorganisms $[4,6,7,14]$.

In general, the antibacterial activities of essential oils could be attributed to the most abundant components or the synergistic effects between its major components and minor ones in the oils

${ }^{3}$ National Institute of Science and Technology. NIST Chemistry Webbook // Data from NIST Standard Reference Database 69, 2018. 
Thin D. B., Thanh V. Q., Thinh B. B. Chemical composition and antimicrobial activity ...

Тхин Д. Б., Тхань В. К., Тхинь Б. Б. Химический состав и антимикробная активность ...

Table 1. Chemical constituents of essential oils from the leaves and rhizomes of $A$. muricarpum

Таблица 1. Химический состав эфирных масел из листьев и корневищ A. muricarpum

\begin{tabular}{|c|c|c|c|c|}
\hline \multirow{2}{*}{ Compound name ${ }^{a}$} & \multirow{2}{*}{$\mathrm{RI}^{\mathrm{b}}$} & \multirow{2}{*}{$\mathrm{RI}^{\mathrm{c}}$} & \multicolumn{2}{|c|}{ Percentage composition $^{d}$} \\
\hline & & & Leaves & Rhizomes \\
\hline Tricyclene & 928 & 927 & 0.15 & 0.21 \\
\hline$\alpha$-Pinene & 939 & 932 & 40.45 & 48.10 \\
\hline Camphene & 955 & 954 & 1.15 & 0.96 \\
\hline$\beta$-Pinene & 980 & 979 & 10.31 & 20.32 \\
\hline$\beta$-Myrcene & 990 & 988 & 3.05 & 1.46 \\
\hline a-Phellandrene & 1006 & 1003 & 0.42 & 0.22 \\
\hline$\delta$ ठ-3-Carene & 1010 & 1007 & - & 0.32 \\
\hline a-Terpinene & 1017 & 1014 & - & 0.21 \\
\hline$p$-Cymene & 1026 & 1020 & 0.15 & - \\
\hline$\beta$-Phellandrene & 1028 & 1024 & 1.52 & 0.41 \\
\hline Limonene & 1032 & 1024 & 0.45 & 0.23 \\
\hline 1,8-Cineole & 1035 & 1030 & - & 0.14 \\
\hline (Z)- $\beta$-Ocimene & 1045 & 1032 & 0.17 & - \\
\hline$(E)-\beta$-Ocimene & 1051 & 1044 & - & 0.23 \\
\hline y-Terpinene & 1061 & 1056 & 0.50 & 0.85 \\
\hline$\alpha$-Terpinolene & 1091 & 1086 & 1.21 & 2.31 \\
\hline Linalool & 1100 & 1095 & 12.34 & 7.56 \\
\hline Borneol & 1166 & 1165 & 0.21 & 0.30 \\
\hline Terpinen-4-ol & 1177 & 1174 & - & 0.51 \\
\hline$\alpha$-Terpineol & 1189 & 1187 & - & 0.23 \\
\hline Fenchyl acetate & 1228 & 1225 & 0.54 & 0.11 \\
\hline Geraniol & 1253 & 1249 & 1.24 & 0.23 \\
\hline Bornyl acetate & 1289 & 1287 & 0.12 & 0.56 \\
\hline Bicycloelemene & 1327 & 1325 & 0.98 & - \\
\hline a-Cubebene & 1351 & 1345 & 0.35 & - \\
\hline a-Copaene & 1377 & 1374 & 0.62 & 0.59 \\
\hline Geranyl acetate & 1381 & 1380 & 3.26 & 1.12 \\
\hline$\beta$-Bourbonene & 1385 & 1384 & - & 0.28 \\
\hline$\beta$-Elemene & 1391 & 1398 & - & 0.53 \\
\hline a-Gurjunene & 1412 & 1409 & 0.13 & 0.11 \\
\hline$\beta$-Caryophyllene & 1419 & 1417 & 1.95 & 0.72 \\
\hline a-Santalene & 1427 & 1427 & 0.61 & - \\
\hline$\gamma$-Elemene & 1430 & 1437 & 0.27 & 0.47 \\
\hline trans- $\alpha$-Bergamotene & 1435 & 1431 & 0.23 & - \\
\hline Aromadendrene & 1441 & 1439 & - & 0.35 \\
\hline (Z)- $\beta$-Farnesene & 1443 & 1440 & 0.56 & 0.89 \\
\hline a-Humulene & 1454 & 1452 & 0.42 & 0.12 \\
\hline$\beta$-Santalene & 1457 & 1457 & - & 0.15 \\
\hline Valencene & 1473 & 1470 & 0.60 & - \\
\hline Y-Gurjunene & 1477 & 1475 & 0.15 & - \\
\hline Germacrene D & 1490 & 1484 & 0.27 & 0.89 \\
\hline a-Selinene & 1493 & 1498 & 1.93 & 1.24 \\
\hline Bicyclogermacrene & 1500 & 1500 & 3.47 & 0.95 \\
\hline$(E, E)$-a-Farnesene & 1508 & 1505 & 2.24 & 1.22 \\
\hline$\gamma$-Cadinene & 1514 & 1513 & 0.24 & 0.54 \\
\hline trans- $\gamma$-Bisabolene & 1516 & 1514 & 0.21 & 0.14 \\
\hline$\alpha$-Panasinsene & 1518 & 1518 & 0.17 & - \\
\hline$\beta$-Sesquiphellandrene & 1524 & 1521 & 0.56 & - \\
\hline$\delta$-Cadinene & 1525 & 1522 & 1.63 & 0.23 \\
\hline Calacorene & 1546 & 1540 & - & 0.28 \\
\hline Germacrene B & 1561 & 1559 & - & 0.84 \\
\hline (E)-Nerolidol & 1563 & 1561 & 0.27 & 0.49 \\
\hline Spathulenol & 1578 & 1577 & 0.31 & - \\
\hline Guaiol & 1601 & 1601 & 0.34 & - \\
\hline a-Cadinol & 1654 & 1652 & 0.52 & - \\
\hline$(E, E)$-Farnesol & 1718 & 1718 & 0.70 & 0.32 \\
\hline Phytol & 2125 & 2124 & 0.21 & 0.16 \\
\hline Total & & & 97.18 & 98.08 \\
\hline Monoterpene hydrocarbons & & & 59.53 & 75.83 \\
\hline Oxygenated monoterpenes & & & 17.71 & 10.76 \\
\hline Sesquiterpene hydrocarbons & & & 17.59 & 10.52 \\
\hline Oxygenated sesquiterpenes & & & 2.14 & 0.81 \\
\hline Others & & & 0.21 & 0.16 \\
\hline
\end{tabular}

${ }^{a}$ Elution order on HP-5MS column; ${ }^{b}$ Retention indices on HP-5MS column; ${ }^{\circ}$ Literature retention indices; ${ }^{d}$ Standard deviation were insignificant and excluded from the Table to avoid congestion; "-" - Not identified. 
Thin D. B., Thanh V. Q., Thinh B. B. Chemical composition and antimicrobial activity ...

Тхин Д. Б., Тхань В. К., Тхинь Б. Б. Химический состав и антимикробная активность ...

Table 2. Antimicrobial activity of $A$. muricarpum essential oils

Таблица 2. Антимикробная активность эфирных масел A. Muricarpum

\begin{tabular}{|l|c|c|}
\hline \multicolumn{1}{|c|}{ Microorganisms } & \multicolumn{2}{c|}{ Minimum inhibitory concentration $(\mathrm{MIC}, \mu \mathrm{g} / \mathrm{mL})$} \\
\cline { 2 - 3 } & Reaves & na \\
\hline Escherichia coli ATCC 25922 & na & na \\
Pseudomonas aeruginosa ATCC 27853 & na & na \\
Salmonella enterica ATCC 13076 & na & $200.0 \pm 0.147$ \\
Enterococcus faecalis ATCC 299212 & na \\
Staphylococcus aureus ATCC 25923 & $200.0 \pm 0.231$ & $200.0 \pm 0.325$ \\
Bacillus cereus ATCC 14579 & na & na \\
Candida albicans ATCC 10231 & na & \\
\hline
\end{tabular}

Note: na - no activity.

$[19,20]$. As mentioned above, $\alpha$-pinene, $\beta$-pinene and linalool were found to be the most important components in the leaf and rhizome oils of A. muricarpum. The individual components the essential oils such as $\alpha$-pinene, $\beta$-pinene and linalool have been determined for antimicrobial activity, and the results indicated that these compounds exhibited inhibitory effects against microorganisms [20-22]. In addition, the $A$. muricarpum essential oil showed better antimicrobial activity against the Gram-positive bacteria than the Gram-negative bacteria. According to previous studies, this is attributed to the existence of cell wall lipopolysaccharides in the Gram-negative bacteria, which can inhibit the hydrophobic essential oil constituents from diffusing into the cells [22, 23].

\section{CONCLUSIONS}

In summary, this study provides information on the chemical composition and antimicrobial activity of essential oils from the leaves and rhizomes of A. muricarpum. According to GC/MS analyses the major components of leaf oil were $\alpha$-pinene $(40.45 \%)$, linalool $(12.34 \%)$, and $\beta$-pinene $(10.31 \%)$, while rhizome oil consists mainly of $\alpha$-pinene $(48.10 \%), \beta$-pinene $(20.32 \%)$, and linalool $(7.56 \%)$. Also, these compounds may be thought of as the contributing factor to the observed antimicrobial activity of the essential oils against $S$. aureus and $B$. cereus. Thus, the $A$. muricarpum essential oils may be sources of promising antimicrobial agents.

\section{REFERENCES}

1. Ponce A. G., Del Valle C. E., Roura S. I. Natural essential oils as reducing agents of peroxidase activity in leafy vegetables. LWT-Food Science and Technology. 2004;37(2):199-204. https://doi.org/10. 1016/j.Iwt.2003.07.005.

2. Vergis J., Gokulakrishnan P., Agarwal R. K., Kumar A. Essential oils as natural food antimicrobial agents: a review. Critical Reviews in Food Science and Nutrition. 2015;55(10):1320-1323. https://doi. org/10.1080/10408398.2012.692127.

3. Fokou J. B. H., Dongmo P. M. J., Boyom F. F. Essential oil's chemical composition and pharmacological properties. In: Essential oils - oils of nature. IntechOpen Publishers, U.K., 2020, pp. 1-23. https: //doi.org/10.5772/intechopen.86573.

4. Huong L. T., Linh L. D., Dai D. N., Ogunwande I. A. Chemical compositions and antimicrobial activity of essential oils from Amomum velutinum X. E. Ye, Škornièk. \& N. H. Xia (Zingiberaceae) from Vietnam. Journal of Essential Oil Bearing Plants. 2020;23(5):1132-1141. https://doi.org/10.1080/0972 060X.2020.1856005.

5. Lamxay V., Newman M. F. A revision of Amomum (Zingiberaceae) in Cambodia, Laos and Vietnam. Edinburgh Journal of Botany. 2012;69(1):99206. https://doi.org/10.1017/S0960428611000436.

6. Huong L. T., Viet N. T., Sam L. N., Giang C. N., Hung N. H., Dai D. N., et al. Antimicrobial activity of the essential oils from the leaves and stems of Amomum rubidum Lamxay \& N. S. Lý. Boletín Latinoamericano y del Caribe de Plantas Medicinales y
Aromáticas. 2021;20(1):81-89. https://doi.org/10.37 360/blacpma.21.20.1.7.

7. Huong L. T., Viet N. T., Sam L. N., Giang C. N., Hung N. H., Dai D. N., et al. Antimicrobial activity of essential oil from the rhizomes of Amomum rubidum growing in Vietnam. American Journal of Essential Oil and Natural Products. 2019;7(4):11-14.

8. Thinh B. B., Doudkin R. V., Thanh V. Q. Chemical composition of essential oil of Amomum xanthioides Wall. ex Baker from Northern Vietnam. Biointerface Research in Applied Chemistry. 2021; 11(4):12275-12284. https://doi.org/10.33263/BRIAC 114.1227512284.

9. Giang P. M., Son P. T., Matsunami K., Otsuka H. New Diarylheptanoids from Amomum muricarpum Elmer. Chemical and Pharmaceutical Bulletin. 2006;54 (1):139-140. https://doi.org/10.1248/cpb.54.139.

10. Giang P. M., Son P. T., Matsunami K., Otsu$\mathrm{ka} \mathrm{H}$. One new and several minor diarylheptanoids from Amomum muricarpum. Natural Product Research. 2012;26(13):1195-1200. https://doi.org/10. 1080/14786419.2010.545775.

11. Huong L. T., Dai D. N., Thang T. D., Bach T. T., Ogunwande I. A. Volatile constituents of Amomum maximum Roxb and Amomum microcarpum C. F. Liang \& D. Fang: two Zingiberaceae grown in Vietnam. Natural Product Research. 2015;29(15):1469-1472. https://doi.org/10.1080/14786419.2014.1003064.

12. Huong L. T., Dai D. N., Binh N. Q., Chung M. V., Dung D. M. Constituents of essential oil from the Amomum muricarpum C.F. Liang \& D. Fang in Vu 
Thin D. B., Thanh V. Q., Thinh B. B. Chemical composition and antimicrobial activity ...

Тхин Д. Б., Тхань В. К., Тхинь Б. Б. Химический состав и антимикробная активность ...

Quang National Park, Ha Tinh province. In: Proceedings of the 2nd National Conference on the Vietnam Natural Museum System, Hanoi, Vietnam; 2016. p. 452-457.

13. Thin D. B. Chemical Composition of Essential oils from the leaves and roots of Amomum muricarpum C.F. Liang \& D. Fang in Ben En National Park, Thanh Hoa province. In: Proceedings of the 7th National Scientific Conference of Ecology and Biological Resources, Hanoi, Vietnam; 2017. p. 1484-1488.

14. Son N. T., Anh L. T., Thuy D. T. T., Luyen N. D., Tuyen T. T. Essential oils from the aerial part and rhizome of Amomum muricarpum Elmer and their antimicrobial activity. Letters in Applied NanoBioScience. 2022;11(1):3322-3328. https://doi.org/ 10.33263/LIANBS111.33223328.

15. Hendawy S. F., Hussein M. S., El-Gohary A. E., Soliman W. S. Chemical constituents of essential oil in Chervil (Anthriscus cerefolium L. Hoffm.) cultivated in different locations. Journal of Essential Oil Bearing Plants. 2019;22(1):264-272. https://doi.org/ 10.1080/0972060X.2019.1587316.

16. Formisano C., Delfine S., Oliviero F., Tenore G. C., Rigano D., Senatore F. Correlation among environmental factors, chemical composition and antioxidative properties of essential oil and extracts of chamomile (Matricaria chamomilla L.) collected in Molise (South-central Italy). Industrial Crops and Products. 2015;63:256-263. https://doi.org/ 10.1016/j.indcrop.2014.09.042.

17. Elbali W., Djouahri A., Djerrad Z., Saka B., Aberrane S., Sabaou N., et al. Chemical variability and biological activities of Marrubium vulgare L. essential oil, depending on geographic variation and environmental factors. Journal of Essential Oil Research. 2018;30(6):470-487. https://doi.org/10.108 0/10412905.2018.1493405.
18. Thinh B. B., Doudkin R. V., Chac L. D., Chinh H. V., Hong N. T. M., Setzer W. N., et al. Chemical Composition and Antimicrobial Activity of Essential Oils from the Leaves and Stems of Tinomiscium petiolare Hook.f. \& Thomson from Vietnam. Journal of Essential Oil Bearing Plants. 2021;24(3):461-468. https://doi.org/10.1080/097206 0X.2021.1936206.

19. Dai D. N., Huong L. T., Hung N. H., Chinh H. V., Ogunwande I. A. Antimicrobial activity and chemical constituents of essential oil from the leaves of Alpinia globosa and Alpinia tonkinensis. Journal of Essential Oil Bearing Plants. 2020;23(2):322-330. https://doi.org/10.1080/0972060X.2020.1752816.

20. Chen Z., He B., Zhou J., He D., Deng J., Zeng R.-H. Chemical compositions and antibacterial activities of essential oils extracted from Alpinia guilinensis against selected foodborne pathogens. Industrial Crops and Products. 2016;83:607-613. https://doi.org/10.1016/j.indcrop.2015.12.063.

21. Aelenei P., Rimbu C. M., Guguianu E., Dimitriu G., Aprotosoaie A. C., Brebu M., et al. Coriander essential oil and linalool-interactions with antibiotics against Gram-positive and Gram-negative bacteria. Letters in Applied Microbiology. 2019;68(2):156164. https://doi.org/10.1111/lam.13100.

22. Ghavam M., Manca M. L., Manconi M., Bacchetta G. Chemical composition and antimicrobial activity of essential oils obtained from leaves and flowers of Salvia hydrangea DC. ex Benth. Scientific Reports. 2020;10(1). Article number 15647. $10 \mathrm{p}$. https://doi.org/10.1038/s41598-020-73193-y.

23. Salleh W. M. N. H. W., Ahmad F., Yen K. H., Sirat H. M. Chemical compositions, antioxidant and antimicrobial activities of essential oils of Piper caninum Blume. International Journal of Molecular Sciences. 2011;12(11):7720-7731. https://doi.org/ 10.3390/ijms 12117720 .

\section{список источников}

1. Ponce A. G., Del Valle C. E., Roura S. I. Natural essential oils as reducing agents of peroxidase activity in leafy vegetables // LWT-Food Science and Technology. 2004. Vol. 37, no. 2. P. 199-204. https://doi.org/10.1016/j.lwt.2003.07.005.

2. Vergis J., Gokulakrishnan P., Agarwal R. K., Kumar A. Essential oils as natural food antimicrobial agents: a review // Critical Reviews in Food Science and Nutrition. 2015. Vol. 55, no. 10. P. 1320-1323. https://doi.org/10.1080/10408398.2012.692127.

3. Fokou J. B. H., Dongmo P. M. J., Boyom F. F. Essential oil's chemical composition and pharmacological properties. In: Essential oils - oils of nature. IntechOpen Publishers, U.K., 2020, pp. 1-23. https: //doi.org/10.5772/intechopen.86573.

4. Huong L. T., Linh L. D., Dai D. N., Ogunwande I. A. Chemical compositions and antimicrobial activity of essential oils from Amomum velutinum X. E. Ye, Škornièk. \& N. H. Xia (Zingiberaceae) from
Vietnam // Journal of Essential Oil Bearing Plants. 2020. Vol. 23, no. 5. P. 1132-1141. https://doi.org/ 10.1080/0972060X.2020.1856005.

5. Lamxay V., Newman M. F. A revision of Amomum (Zingiberaceae) in Cambodia, Laos and Vietnam // Edinburgh Journal of Botany. 2012. Vol. 69, no. 1. P. 99-206. https://doi.org/10.1017/S0960 428611000436.

6. Huong L. T., Viet N. T., Sam L. N., Giang C. N., Hung N. H., Dai D. N., et al. Antimicrobial activity of the essential oils from the leaves and stems of Amomum rubidum Lamxay \& N. S. Lý // Boletín Latinoamericano y del Caribe de Plantas Medicinales y Aromáticas. 2021. Vol. 20, no. 1. P. 81-89. https:// doi.org/10.37360/blacpma.21.20.1.7.

7. Huong L. T., Viet N. T., Sam L. N., Giang C. N., Hung N. H., Dai D. N., et al. Antimicrobial activity of essential oil from the rhizomes of Amomum rubidum growing in Vietnam // American Journal of Essential 
Thin D. B., Thanh V. Q., Thinh B. B. Chemical composition and antimicrobial activity ...

Тхин Д. Б., Тхань В. К., Тхинь Б. Б. Химический состав и антимикробная активность ...

Oil and Natural Products. 2019. Vol. 7, no. 4. P. 11-14.

8. Thinh B. B., Doudkin R. V., Thanh V. Q. Chemical composition of essential oil of Amomum xanthioides Wall. ex Baker from Northern Vietnam // Biointerface Research in Applied Chemistry. 2021. Vol. 11, no. 4. P. 12275-12284. https://doi.org/10. 33263/BRIAC114.1227512284.

9. Giang P. M., Son P. T., Matsunami K., Otsuka H. New Diarylheptanoids from Amomum muricarpum Elmer // Chemical and Pharmaceutical Bulletin. 2006. Vol. 54, no. 1. P. 139-140. https://doi. org/10.1248/cpb.54.139.

10. Giang P. M., Son P. T., Matsunami K., Otsuka $\mathrm{H}$. One new and several minor diarylheptanoids from Amomum muricarpum // Natural Product Research. 2012. Vol. 26, no. 13. P. 1195-1200. https:// doi.org/10.1080/14786419.2010.545775.

11. Huong L. T., Dai D. N., Thang T. D., Bach T. T., Ogunwande I. A. Volatile constituents of Amomum maximum Roxb and Amomum microcarpum C. F. Liang \& D. Fang: two Zingiberaceae grown in Vietnam // Natural Product Research. 2015. Vol. 29, no. 15. P. 1469-1472. https://doi.org/10.1080/1478 6419.2014.1003064.

12. Huong L.T., Dai D.N., Binh N.Q., Chung M.V., Dung D.M. Constituents of essential oil from the Amomum muricarpum C.F. Liang \& D. Fang in Vu Quang National Park, Ha Tinh province // Proceedings of the 2nd National Conference on the Vietnam Natural Museum System (Hanoi, Vietnam). 2016. P. 452-457.

13. Thin D.B. Chemical Composition of Essential oils from the leaves and roots of Amomum muricarpum C.F. Liang \& D. Fang in Ben En National Park, Thanh Hoa province // Proceedings of the 7th National Scientific Conference of Ecology and Biological Resources (Hanoi, Vietnam). 2017. P. 1484-1488.

14. Son N. T., Anh L. T., Thuy D. T. T., Luyen N. D., Tuyen T. T. Essential oils from the aerial part and rhizome of Amomum muricarpum Elmer and their antimicrobial activity // Letters in Applied NanoBioScience. 2022. Vol. 11, no. 1. P. 3322-3328. https://doi.org/10.33263/LIANBS111.33223328.

15. Hendawy S. F., Hussein M. S., El-Gohary A. E., Soliman W. S. Chemical constituents of essential oil in Chervil (Anthriscus cerefolium L. Hoffm.) cultivated in different locations // Journal of Essential Oil Bearing Plants. 2019. Vol. 22, no. 1. P. 264-272. https://doi.org/10.1080/0972060X.2019.1587316.

16. Formisano C., Delfine S., Oliviero F., Tenore G. C., Rigano D., Senatore F. Correlation among environmental factors, chemical composition and antioxida-

\section{INFORMATION ABOUT THE AUTHORS}

\author{
Dau B. Thin, \\ Cand. Sci. (Biology), Associate Professor, \\ Hong Duc University, \\ 565, Quang Trung St., Thanh Hoa, 40130, \\ Vietnam, \\ https://orcid.org/0000-0002-6351-3335
}

tive properties of essential oil and extracts of chamomile (Matricaria chamomilla L.) collected in Molise (South-central Italy) // Industrial Crops and Products. 2015. Vol 63. P. 256-263. https://doi.org/10.1016/j.indcrop.2014.09.042.

17. Elbali W., Djouahri A., Djerrad Z., Saka B., Aberrane S., Sabaou N., et al. Chemical variability and biological activities of Marrubium vulgare L. essential oil, depending on geographic variation and environmental factors // Journal of Essential Oil Research. 2018. Vol. 30, no. 6. P. 470-487. https://doi. org/10.1080/10412905.2018.1493405.

18. Thinh B. B., Doudkin R. V., Chac L. D., Chinh H. V., Hong N. T. M., Setzer W. N., et al. Chemical Composition and Antimicrobial Activity of Essential Oils from the Leaves and Stems of Tinomiscium petiolare Hook.f. \& Thomson from Vietnam // Journal of Essential Oil Bearing Plants. 2021. Vol. 24, no. 3. P. 461-468. https://doi.org/10. 1080/0972060X.2021.1936206.

19. Dai D. N., Huong L. T., Hung N. H., Chinh H. V., Ogunwande I. A. Antimicrobial activity and chemical constituents of essential oil from the leaves of Alpinia globosa and Alpinia tonkinensis // Journal of Essential Oil Bearing Plants. 2020. Vol. 23, no. 2. P. 322330. https://doi.org/10.1080/0972060X.2020.1752816.

20. Chen Z., He B., Zhou J., He D., Deng J., Zeng R.-H. Chemical compositions and antibacterial activities of essential oils extracted from Alpinia guilinensis against selected foodborne pathogens // Industrial Crops and Products. 2016. Vol. 83. P. 607613. https://doi.org/10.1016/j.indcrop.2015.12.063.

21. Aelenei P., Rimbu C. M., Guguianu E., Dimitriu G., Aprotosoaie A. C., Brebu M., et al. Coriander essential oil and linalool-interactions with antibiotics against Gram-positive and Gram-negative bacteria // Letters in Applied Microbiology. 2019. Vol. 68, no. 2. P. 156-164. https://doi.org/10.1111/lam.13100.

22. Ghavam M., Manca M. L., Manconi M., Bacchetta G. Chemical composition and antimicrobial activity of essential oils obtained from leaves and flowers of Salvia hydrangea DC. ex Benth // Scientific Reports. 2020. Vol. 10, no. 1. Article number 15647. $10 \mathrm{p}$. https://doi.org/10.1038/s41598-020-73193-y.

23. Salleh W. M. N. H. W., Ahmad F., Yen K. H., Sirat H. M. Chemical compositions, antioxidant and antimicrobial activities of essential oils of Piper caninum Blume // International Journal of Molecular Sciences. 2011. Vol. 12, no. 11. P. 7720-7731. https://doi.org/10.3390/ijms12117720.

\section{СВЕДЕНИЯ ОБ АВТОРАХ}

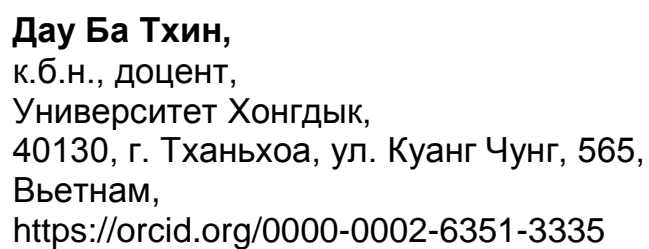


Thin D. B., Thanh V. Q., Thinh B. B. Chemical composition and antimicrobial activity ...

Тхин Д. Б., Тхань В. К., Тхинь Б. Б. Химический состав и антимикробная активность ...

\section{Vu Q. Thanh,}

Researcher,

Vietnam-Russia Tropical Center,

Nguyen Van Huyen St., Hanoi, 11300,

Vietnam,

https://orcid.org/0000-0002-8783-9014

\section{Bui B. Thinh,}

Researcher,

Far Eastern Federal University,

10, Ajax Bay, Russky Island,

Vladivostok, 690922,

Russian Federation,

buibaothinh9595@gmail.com

https://orcid.org/0000-0002-3826-1199

\section{Contribution of the authors}

The authors contributed equally to this article.

\section{Conflict interests}

The authors declare no conflict of interests regarding the publication of this article.

The final manuscript has been read and approved by all the co-authors.

Information about the article

The article was submitted 05.10.2021.

Approved after reviewing 15.11.2021.

Accepted for publication 30.11.2021.

\section{Ву Кует Тхань,}

научный сотрудник,

Российско-Вьетнамский Тропический центр,

11300 , г. Ханой, ул. Нгуен Ван Хуен,

Вьетнам,

https://orcid.org/0000-0002-8783-9014

\section{Буй Бао Тхинь,} научный сотрудник,

Дальневосточный федеральный университет, 690922, г. Владивосток, о. Русский, п. Аякс, 10, Российская Федерация, buibaothinh9595@gmail.com https://orcid.org/0000-0002-3826-1199

\section{Вклад авторов}

Все авторы сделали эквивалентный вклад в подготовку публикации.

\section{Конфликт интересов}

Авторы заявляют об отсутствии конфрликта интересов.

Все авторы прочитали и одобрили окончательный вариант рукописи.

\section{Информация о статье}

Поступила в редакцию 05.10.2021.

Одобрена после рецензирования 15.11.2021.

Принята к публикации 30.11.2021. 